Linguistik Terapan 16 (1) (2019): 291-298

Jurnal Linguistik Terapan Pascasarjana

Available online

http://jurnal.unimed.ac.id/2019/index.php/JLT-Unimed

\title{
THE VERBAL AND VISUAL ELEMENTS OF BEAUTY PRODUCT ADVERTISEMENTS IN INDONESIAN WOMEN'S MAGAZINES
}

\author{
Yuni Khairina \\ Busmin Gurning \\ Zainuddin
}

\author{
English Applied Linguistics Program \\ Postgraduate Program - Universitas Negeri Medan
}

Diterima Desember 2018; Disetujui Februari 2019; Dipublikasikan April 2019

\section{ABSTRACT}

As the development of technology, advertisers who use print media utilize image and text to achieve its economic goals. In trying to understand meaning within the advertisement, we should be able to read and interpret all the semiotic resources. This study was aimed at investigating the verbal and visual elements found in beauty product advertisements in Indonesian women's magazine. The data were the multimodal clauses of 12 beauty products advertisements taken from three Indonesian women's magazines, namely Femina, Cosmopolitan Indonesia and her world Indonesia which were published in March 2018 by using snowball sampling technique. In order to identify the verbal and visual elements, Cheong (2004) framework of generic structure advertisement was used. The findings showed that Display which serves to describe the product in a real and explicit way and Enhancer as the linguistic element which function is to give detail explanation about the product appear to be the obligatory elements in beauty product print advertisement. Meanwhile, elements like Lead, Announcement, Emblem, Tag, Call and Visit Information are optional in the structure of print advertisements. Thus, it is found a new GSP of beauty product advertisement as following: (Lead)^ Display^ $(\text { Announcement })^{\wedge}$ Enhancer $^{\wedge}(\text { Emblem })^{\wedge}(\text { Tag })^{\wedge}($ Call and Visit Information $)$.

Keywords: Verbal and Visual, Beauty Advertisements, Indonesian Women's Magazine

How to Cite: Khairina, Yuni. 2019.

The Verbal and Visual Elements of Beauty Product Advertisements in Indonesian Women's Magazines. Jurnal Linguistik Terapan Pascasarjana Unimed. 16 (1): 291-298

*Corresponding author:

ISSN 0216-5139

E-mail: yunikhairina92@gmail.com 


\section{INTRODUCTION}

Advertising is an important and simple procedure for companies to make themselves known. As the development of technology, advertisers who use print media utilize image and text to achieve its economic goals. Beauty product is one of the examples of advertisement which has stiff competition in the market. In print media like women magazine are constantly flooded with beauty product advertisements. For women as their target, such techniques are employed to convince that their product is the best. As Tan and O' Halloran (2012: 1) claimed that one of the most common persuasive techniques used by advertisers is to depict images of attractive, wealthy, or otherwise glamorous people, such as beautiful models with flawless skin or popular artists (e.g. singers, actors, entertainers) who either use or endorse the product or service. Thus, this may lead women to vast perception in order to understand the product.

Advertisements are highly influenced by the social or cultural context and situation where they are published/ produced. In trying to understand meaning within the advertisement, we should be able to read and interpret all the semiotic resources. Thus, it is important to not just look at the literal meaning of the advertisement, but analyze both elements to see what the commercial is really telling us, or what it is really selling. Unfortunately, many studies of advertising do separate out components of ads, concentrate on one or a few, and ignore the others (Cook, 2001: 2). Hence, it is necessary to conduct a study related to multimodal analysis in order to find out the verbal and visual elements used by advertisement producers in promoting their product.

\section{a. Multimodal Analysis}

Multimodal Analysis is an approach to analysis that analyzes visual as well as verbal means of communication (Young \& Fitzgerald, 2006:212). Van Leeuwen in Liu (2013) defines it as the combination of different semiotic modes - for example, language and music - in a communicative artifact or event. According to Baldry and Thibault (2006:21), multimodality refers to the diverse ways in which a number of distinct semiotic resource systems are both "code-played" and co-contextualized in making meaning of a text - specific meaning. Further, Kress \& van Leeuwen in Bell and Garrett (2001:187) claimed that language is always realized through and accompanied by other semiotic modes. When people speak, they articulate the messages not only using words but also through a combination of speech sound, rhythm, intonation and accompanied by facial expression, gesture and posture. 
They use multimodal. Thus, multimodal is the combination of several modes of communication such as language, image, facial expression, intonation and other semiotics type which cannot be neglected in order to get a specific meaning.

\section{b. Multimodal in Print Advertisement}

Cheong (2004) proposes a working systemic functional model for meaning making in print advertisements through proposing lexico-grammatical strategies for ideational, interpersonal and textual meaning. In her research on four print advertisements in Singapore, Cheong found that the generic structure of print advertisement is as the following: Lead $\wedge$ $(\text { Display })^{\wedge}$ Emblem $^{\wedge}($ Announcement $) \wedge($ Enhancer $) \wedge($ Tag $) \wedge($ Call-and-Visit Information $)$.

Table I. The Generic Structure of Print Advertisement

\begin{tabular}{ll}
\hline Verbal Component & Visual Component \\
\hline Announcement: & Lead: Locus of \\
Primary, Secondary & Attention (LoA), \\
Enhancer & Complement to the \\
Emblem & Locus of Attention \\
Tag & (Comp. LoA) \\
Call - and - visit & Display: Explicit, \\
information & Implicit, Congruent, \\
& Incongruent \\
& (metaphorical) \\
& Emblem \\
\hline
\end{tabular}

(Lubis, 2014: 164)

The visual component in print advertisement is Lead. This component plays an important role in print advertisements, it is interpersonally most salient through the choice in size, position and/ or color which should have the potential to create an impression and meaning for the user. Cheong in O'Halloran (2004: 165) classifies the components of Lead into (1) Locus of Attention (LoA) which serves as the core of advertising messages, displayed in the size and color with distinctive quality compared with other visual components; and (2) Complement to the Locus of Attention (Comp. LoA) which functions as a liaison and to focus public attention on specific parts in LoA. The ideational function that LoA serves in explaining the reality created by the advertiser is to attract attention and interest of society to this reality. The interpersonal function is to attract the attention of the audiences and its textual function serves as a spring board for the development of core messages.

The visual component Display serves to describe the product in a real and explicit way, but the implicit function shown here is the realization of products or services that are not real to become real through another medium. Meanwhile, the visual component display 
Congruent serves to realize a product without going through symbolization and display Incongruent realizes a product through symbolization.

The visual component Emblem is visually realized through the advertised product logos while in the linguistic is form of a brand name or trademark. Emblem provides identity or status for the product lying on any side to adjust the proportion of the advertisement texts.

Announcement is the most salient linguistic item in an advertisement. Primary Announcement contains three meanings, that is: 1) as the only one advertisement message, 2) important part interpersonally between the other messages in a text, 3) as a catch - phrase. Secondary Announcement is the less interpersonally salient announcement/s among other announcements in the same advertisement. (Cheong in O'Halloran, 2004: 173).

Enhancer usually appears in the form of paragraph. Enhancer function is to develop or modify a meaning which comes from interaction between Lead and Announcement. Ideationally, Enhancer functions to show the power of the product so that it's deserved to be consumed. Interpersonally, Enhancer functions to influence the public. Thus, Enhancer contains words emotionally and culturally, the words that contains values in a social system. Logically, Enhancer explains the relationships among clauses (Cheong in O'Halloran, 2004:173).

Tag is usually in the form of one-liners in small print and typically non-salient. It is usually realized as non-finite. While the linguistic component Call - and - Visit Information is the information that can be contacted by the user community who wish to obtain the advertised product, and usually Call-and-Visit Information is printed in small fonts in certain parts of the advertisement product. (Cheong in O'Halloran, 2004: 174).

\section{c. Beauty Product Advertisement}

Beauty product advertising is the promotion of cosmetics and beauty products by the cosmetics industry through a variety of media. The advertising campaigns are usually aimed at women wishing to improve their appearance, commonly to increase physical attractiveness and reduce the signs of ageing. As Baudrillard (2005) points out that many advertisements in women's magazines that advertise beauty products influence women and women feel pressure to look beautiful and to do their best to hold their beauty. Welsch (1996) and Reischer and Koo (2007) claimed that the "ideal" woman is stereotypically represented by means of visual and linguistic elements in advertisements. Featherstone (1991) pays attention to the sensational attempts of advertisers to modify and beautify the body through certain consumption practices. To emphasize these attempts, he also points out the use of celebrity 
models in beauty product advertisements. These commercials inform the consumer about the parameters of looking beautiful, while at the same time prescribe an ideal for what beautiful should look like externally (Featherstone, 1991).

\section{RESEARCH METHOD}

This research was conducted in a qualitative research. The data of this study were the clauses and multimodal of 12 beauty products advertisement found in Indonesian women's magazines. Any elements of print advertisement such as slogan, logo, model, and the text were collected as data of this research.

The data sources of this research were 12 beauty product advertisements taken from three Indonesian women's magazines, namely Femina, Cosmopolitan Indonesia and her world Indonesia which were published in March 2018. Those magazines were selected since they were best seller women magazine in Indonesia based on www.w3newspapers.com in 2017. Four beauty product advertisements from each magazine were taken as their representative by using snowball sampling technique. As Ary, Jacobs, Sorensen and Razavieh (2010:430) stated that snowball sampling may occur when potential respondents are not centrally located but scattered in different sites.

The technique of data analysis of this study used interactive model. Miles, Huberman and Saldana (2014:31) state that there are three steps used to analyze the data, they are data condensation, data display, and conclusion drawing or verification.

\section{RESEARCH FINDINGS}

The beauty product advertisements which consist of multimodal were selected as the data of this study. The data selected are then categorized based on the generic structure of print advertisements as proposed by Cheong (2004), particularly being identified whether they belong to any types of verbal and visual elements of print advertisement. The classification based on its generic structure is described as the following:

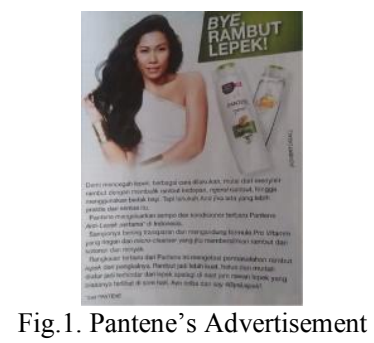

The analysis of Pantene's advertisement taken from Femina magazine. For verbal elements, the text "BYE, RAMBUT LEPEK!" (bye, dull hair!) is found as the primary announcement of the advertisement because it is the most salient linguistic item that typed 
in capital font and bigger size than any other text. The text is also short, to captures the essence of intended message the advertisers wish to foreground to the consumers. While the rest of the texts which appear in paragraph form belong to Enhancer, its function is to persuade and influence readers to purchase the product. \#ByeLepek which appears at the last sentence is considered as call and visit information since we live in social media age, where hash-tag has become a keyword to find out information on the internet.

In visual, it shows that picture of the model touches her hair which is the most salient visual is categorized as the Lead (LoA) since it is able to arrest readers' attention. The setting is white background which means no Comp. LoA to support the LoA. On the right side is the display which shows 2 shampoo's bottles are categorized as explicit and congruent because those are the real picture of Pantene's product. No emblem is put in any side of the advertisement since the brand or logo of the product is already presented in the bottle of the product (Display).

After having analysed the data, this study indicates that only Display and Enhancer occur in 12 beauty product advertisements which have been analysed. The tabulation of verbal and visual elements' occurrence are shown in the Table II.

Table II. The Tabulation of Verbal and Visual Elements' Occurrence

\begin{tabular}{llcc}
\hline Element & $\begin{array}{c}\text { Number of } \\
\text { Occurrences }\end{array}$ & $\begin{array}{c}\text { Percentage } \\
(\boldsymbol{\%})\end{array}$ \\
\hline \multirow{5}{*}{ Verbal } & Announcement & 11 & 91 \\
& Enhancer & 12 & 100 \\
& Tag & 1 & 8.3 \\
& Emblem & 2 & 17 \\
& Call and Visit & 4 & 33.3 \\
\hline \multirow{2}{*}{ Visual } & Information & & \\
\hline \multirow{2}{*}{ Lead } & Display & 12 & 58.3 \\
& & & 100 \\
\hline
\end{tabular}

Table II indicates that only Display and Enhancer elements always occur in the 12 beauty product advertisements. It shows that the visual component Display which serves to describe the product in a real and explicit way is crucial in beauty product print advertisement in order to introduce the readers the picture of the product that the advertiser wants to offer. Meanwhile, as the linguistic element, Enhancer appears to be the obligatory element in beauty product print advertisement. Since its function is to show the power of the product so that it's deserved to be consumed by the consumer, thus the advertisers use it as one of the strategies to attract their customers. Based on the analysis in the table above the Generic Structure Potential of beauty product advertisements in Indonesian women's magazine is as the following: $(\text { Lead })^{\wedge} \operatorname{Display}^{\wedge}(\text { Announcement })^{\wedge}$ Enhancer $^{\wedge}(\text { Emblem })^{\wedge}(\text { Tag })^{\wedge}($ Call and Visit Information). 


\section{DISCUSSION}

Cheong (2004) analysed four print advertisements and claimed that Lead and Emblem is the crucial elements in print advertisement. She stated that Lead plays an important role in print advertisements since it is interpersonally most salient through the choice in size, position and/ or colour which should have the potential to create an impression and meaning for the user while Emblem provides identity or status for the product lying on any side to adjust the proportion of the advertisement texts.

However, in beauty product advertisement Display which serves to describe the product in a real and explicit way is crucial in beauty product print advertisement in order to introduce the readers the picture of the product that the advertiser wants to offer. Meanwhile, as the linguistic element, Enhancer appears to be the obligatory element in beauty product print advertisement. Since its function is to show the power of the product so that it's deserved to be consumed by the consumer. The brand or logo of the product is already presented in the bottle of the product (Display), so the advertisement writers do not need to put it on any other side of the advertisement.

\section{CONCLUSION}

There are two elements that are found as the obligatory elements in 12 beauty product advertisements, namely Enhancer (verbal) and Display (visual). Meanwhile, elements like Lead, Announcement, Emblem, Tag, Call and Visit Information are optional in the structure of beauty product advertisements.

\section{References}

Ary, D., Jacobs, L.C., Sorensen, C. and Razavieh, A. 2010. Introduction to Research in Education. 8th Edition. Belmont: Wadsworth

Baldry, A and Thibault, P.J. 2006. Multimodal Transcription and Text Analysis. London: Equinox Halliday, M.A.K. 1994. An Introduction to Functional Grammar. Second Edition London: Edward Arnold.

Baudrillard, J. 2005. The Finest Consumer Object: The Body. In M. Fraser, \& M. Greco (Eds.), The Body: A Reader (pp. 277-282). London and New York: Routledge.

Bell, A and Garrett, P. 2001. Media Discourse. Oxford: Blackwell Publishers.

Cook, G. 2001. The Discourse of Advertising. London: Routledge

Liu, J. 2013. Visual Images Interpretive Strategies in Multimodal Texts. Journal of Language Teaching and Research. 4(6)

Lubis, D.S. 2014. The Structure of Selected Print Advertisement: A Multimodal Analysis. Kajian Linguistik. Vol. 11 (1) 
Miles, M.B. and Huberman, A.M. 1994. Qualitative Data Analysis. London: SAGE Publications.

O’Halloran, K.L. 2004. Multimodal Discourse Analysis. Systemic Functional Perspectives. London: Continuum. 